\title{
PERILAKU PETANI TERHADAP ADOPSI TEKNOLOGI M-BIO UNTUK PENGEMBANGAN USAHATANI AGROFORESTRI
}

\author{
Rudi Priyadi, Rina Nuryati, Faqihuddin* \\ Fakultas Pertanian, Universitas Siliwangi \\ Email: rudipriyadi@unsil.ac.id, rinanuryati@unsil.ac.id, faqihuddin@unsil.ac.id \\ ${ }^{*}$ Penulis korespondensi
}

\begin{abstract}
This study aims to determine the behavior of farmers in adopting M-Bio technology for the development of agroforestry farming. The research method is a survey with data collection techniques: observation and in-depth interviews with respondents. Research variables include farmer behavior towards the implementation of counseling and training as well as farmer behavior towards the adoption of M-Bio Technology. The research was conducted in Setiawaras Village in the Cipigan Insan Mandiri and Dadap Sari farmer groups from July to October 2020. The data analysis used was descriptive analysis with a Likert scale with scores of 1, 2, 3, 4, and 5 then measured by weighted values. The data distribution was converted into a ratio scale with a score between 0-100. Furthermore, the scores are grouped into: (1) Very Low: 020; (2) Low: 21 - 40; (3) Moderate: 41-60; (4) Height: 61-80; and (5) Very High: 81-100. The results showed that the behavior of farmers towards the implementation of counseling and training on M-Bio technology with all its indicators (presentation and practice, attention, comprehensiveness, results and retention) had a score between $80-100$ so all of them were categorized as very high. Likewise, the behavior of farmers towards the adoption of M-Bio technology for the development of agroforestry farming along with all its indicators concerning cognitive, apective, and conative aspects has a score between $80-100$ so that all of them are also categorized as very high.
\end{abstract}

Keywords: Agroforestry Farmin;, Behavior; M-Bio.

\begin{abstract}
Abstrak
Penelitian bertujuan untuk mengetahui perilaku petani dalam adopsi teknologi M-Bio untuk pengembangan usahatani agroforestri. Metode penelitian adalah survey dengan teknik pengumpulan data : observasi dan wawancara mendalam dengan responden. Varibel penelitian mencakup perilaku petani terhadap pelaksanaan penyuluhan dan pelatihan serta perilaku petani terhadap adopsi Teknologi M-Bio. Penelitian dilaksanakan di Desa Setiawaras pada kelompok tani Cipigan Insan Mandiri dan Dadap Sari dari bulan Juli sampai Oktober 2020. Analisis data yang digunakan adalah analisis deskriptif dengan skala likert skor 1, 2, 3, 4, dan 5 kemudian diukur dengan nilai tertimbang. Sebaran data diubah menjadi skala rasio dengan skor antara 0-100. Selanjutnya, skor dikelompokkan menjadi : (1) Sangat Rendah:020; (2) Rendah:21 - 40; (3) Sedang:41-60; (4) Tinggi:61-80; dan (5) Sangat Tinggi: 81-100. Hasil penelitian menunjukkan bahwa perilaku petani terhadap pelaksanaan penyuluhan dan pelatihan teknologi M-Bio dengan seluruh indikatornya (presentasi dan praktek, atensi, komprehensif, hasil dan retensi) memiliki skor antara 80 - 100 sehingga semuanya terkategori sangat tinggi. Demikian juga dengan perilaku petani terhadap adopsi teknologi M-Bio untuk pengembangan usahatani agroforestri beserta seluruh indikatornya yang menyangkut aspek kognitif, apektif, dan konatif memiliki skor antara $80-100$ sehingga semuanya juga terkategori sangat tinggi.
\end{abstract}

Kata Kunci: M-Bio; Perilaku; Usahatani Agroforestri. 


\section{PENDAHULUAN}

Pembangunan

pertanian merupakan bagian dari pembangunan wilayah, harus dilakukan sesuai dengan keadaan sosial ekonomi daerah, kondisi lahan dan potensi pasar. Tujuan peningkatan produktivitas dan produksi serta keberlanjutan sistem produksi, dan peningkatan kesejahteraan petani yang diikuti dengan pelestarian lingkungan merupakan tujuan yang harus tetap sejalan dan seimbang untuk dicapai oleh negara kita dalam upaya mewujudkan pembangunan pertanian berkelanjutan.

Fikagandhi (2012), menjelaskan pada era globalisasi sekarang ini, banyak dijumpai krisis ekologi yang timbul akibat dari keseimbangan alam yang terganggu. Tanpa disadari berbagai tindakan dan sikap kita telah menyebabkan terjadinya kerusakan ekologi. Aplikasi teknologi yang tidak tepat dapat mengganggu keseimbangan alam. Sehubungan dengan hal tersebut kita perlu mengembangkan dan melestarikan kembali kearifan lokal yang ada di masyarakat pedesaan.

Kearifan lokal merupakan suatu bentuk warisan budaya Indonesia yang telah berkembang sejak lama. Kearifan lokal lahir dari pemikiran dan nilai yang diyakini suatu masyarakat terhadap alam dan lingkungannya. Di dalam kearifan lokal terkandung nilai-nilai, normanorma, sistem kepercayaan, dan ide-ide masyarakat setempat. Oleh karena itu kearifan lokal di setiap daerah berbedabeda. Suhartini (2009) menyatakan bahwa kearifan lokal ikut berperan dalam pengelolaan sumberdaya alam dan lingkungannya. Pengetahuan mengenai kearifan lokal yang dimiliki masyarakat yang diturunkan secara turun temurun serta inovasi dan teknologi juga mempengaruhi keberlangsungan kearifan lokal di masa depan. Pemerintah sebagai pemegang kekuasaan sudah saatnya memberlakukan kebijakan terkait adopsi teknologi penggunaannya serta difusi teknologi yang melindungi sumberdaya alam dan lingkungan melalui kearifan lokal.

Menelaah sejarah perkembangan penggunaan lahan, di dunia termasuk di Indonesia sesungguhnya telah terdapat sistem penggunaan lahan yang mendukung sistem berkelanjutan sumber daya lahan yaitu dengan sistem tanam campuran atau polikultur. Ris Irianto (2010) menjelaskan bahwa penanaman pola agroforestri dikenal pula dengan nama pola polikultur bermanfaat untuk meningkatkan pendapatan petani, sekaligus dapat menjaga dan memperbaiki lingkungan. Pola polikultur/ agroforest mempunyai fungsi ekonomi penting bagi masyarakat, karena sistem ini bertumpu pada keragaman struktur dan unsur-unsurnya yang tidak terkonsentrasi pada satu spesies saja.

Usahatani Agroforestri saat ini banyak dilakukan oleh petani di Kabupaten Tasikmalaya dengan mengusahakan tanaman perkebunan diantara tanaman kayu-kayuan dan tanaman lainnya disertai dengan pengelolaan usaha ternak dan ikan. Hal ini berkaitan dengan PP No.2 Tahun 2005 tentang RTRW yang menjelaskan 
bahwa Kabupaten Tasikmalaya Selatan merupakan salah satu wilayah Jabar Selatan yang memiliki potensi sumber daya alam wilayah setempat antara lain untuk pengembangan usahatani perkebunan. Usaha tanaman perkebunan di Kabupaten Tasikmalaya sebagian besar merupakan perkebunan yang dimiliki oleh masyarakat atau petani.

Usahatani

Agroforestri

dilaksanakan oleh petani di Kabupaten Tasikmalaya dengan berbagai keterbatasan yang ada pada diri mereka, umumnya memiliki tingkat produktivitas yang rendah. Hal ini bisa dilihat diantaranya dari rata-rata produktivitas tanaman kakao dan kopi yang masingmasing hanya mencapai 0,50 ton/ha untuk tanaman kakao dan 0,49 ton/ha untuk tanaman kopi (Statistik Perkebunan Tahun 2013 Kab. Tasikmalaya), padahal potensi produksi kakao dapat mencapai 2,16-3,20 ton/ha (Tri Haryanto, 2012) dan untuk tanaman kopi bisa mencapai 0,5-1,2 ton/ha (Djaenudin, et al., 2003).

Rendahnya produktivitas tanaman yang diusahakan pada usahatani agroforestri dari hasil survey pendahuluan diketahui disebabkan oleh teknis budidaya yang dilakukan petani tidak optimal. Diantaranya adalah pemupukan jarang dilakukan padahal potensi sumber bahan organik dari hijauan pada pola agroforestri tanaman tanaman banyak tersedia baik dari daun, ranting maupun cabang termasuk dari kulit buah sisa panen kakao maupun tanaman yang lainnya. Demikian juga dengan penyiangan hanya dilakukan seperlunya sehingga gulma banyak tumbuh disekitar tanaman yang menjadi kompetitor tanaman yang diusahakan. Pemangkasan juga jarang dilaksanakan akibatnya percabangan tanaman menjadi tidak beraturan dan kondisi lahan menjadi lembab yang meningkatkan serangan hama dan penyakit Phytophthora palmivora.

Kondisi usahaternak juga tidak jauh berbeda dengan keadaan tanaman yang diusahakan, meskipun usahaternak ini telah menjadi bagian dari keseharian petani dan memegang peranan penting bagi pendapatan rumah tangga petani. Namun seperti kondisi peternakan rakyat pada umumnya, usaha ternak domba/kambing yang mereka lakukan masih sederhana dengan jumlah pemeliharaan hanya 2 ekor/petani, dan hanya bersifat sebagai usaha sampingan. Ternak domba/kambing diperlihara dengan cara dikandangkan, kondisi kandang terlihat kurang terawat dengan ceceran sisa pakan dan kotoran yang tersebar di sekitar kandang sehingga produksi dan produktivitas ternak yang dihasilkan rendah. Ceceran sisa pakan dan kotoran ternak yang ada pada lahan agroforestri juga berpotensi untuk dimanfaatkan sebagai bahan pupuk organik untuk diaplikasikan pada tanaman agroforestri dan hijauan dari tanaman agroforestri dapat dimanfaatkan sebagai sumber pakan pada usaha ternak. Usaha perikanan kondisinya tidak jauh berbeda dengan kondisi usaha peternakan yang ditekuni petani hanya sebagai usaha sampingan dengan pemeliharaan seadanya tanpa sentuhan teknologi untuk membantu peningkatan produksi dan produktivitasnya. 
Sehubungan dengan hal tersebut maka dilakukan diseminasi teknologi kepada masyarakat untuk diadopsi pada usahatani agroforestri agar produktivitasnya meningkat. Salah satu teknologi yang telah diuji dan dikembangkan oleh Fakultas Pertanian Universitas Siliwangi Tasikmalaya adalah Teknologi M-Bio. Teknologi ini telah diaplikasikan baik pada tanaman, ternak maupun ikan dan telah mengalami proses panjang untuk dapat dibuktikan pengaruhnya dalam mendukung pertumbuhan dan perkembangan tanaman, ternak dan ikan.

Proses adopsi inovasi yang terjadi pada diri petani merupakan proses kejiwaan/mental pada saat menghadapi suatu inovasi, mulai dari proses menerima atau menolak ide baru atau adopsi juga diartikan sebagai proses mental seseorang dari mendengar, mengetahui inovasi sampai akhirnya mengadopsi. Menurut Mardikanto (1993) adopsi dalam penyuluhan pertanian dapat diartikan sebagai proses perubahan perilaku baik yang berupa pengetahuan, sikap, maupun keterampilan pada diri seseorang setelah menerima "inovasi" yang disampaikan penyuluh kepada sasarannya. Penerimaan disini mengandung arti tidak sekedar "tahu" tetapi dengan benarbenar dapat dilaksanakan atau diterapkan dengan benar serta menghayatinya. Penerimaan inovasi tersebut, biasanya dapat diamati secara langsung maupun tidak langsung oleh orang lain sebagai cerminan dari adanya perubahan sikap, pengetahuan, dan keterampilannya.
Pangabean, $\quad d k k \quad$ (2016) menyatakan bahwa persepsi petani terhadap diseminasi suatu teknologi yang baik adalah melalui demontrasi plot. Sementara itu, kajian Yuniarsih, dkk (2020) menunjukkan bahwa korelasi sikap petani dengan keputusan mengadopsi suatu teknologi sangat dipengaruhi faktor intenal (pengetahuan dan pengalaman) dan faktor eksternal (kesesuaian lahan, kemudahan berusahatani, ketersediaan sarana dan prasarana, dan dukungan kelompok tani).

Kajian ini dilakukan dengan tujuan untuk mengetahui perilaku petani terhadap adopsi teknologi M-Bio untuk pengembangan usahatani agroforestri. Kegunaan dari penelitian ini adalah untuk mendayagunakan teknologi yang dihasilkan guna membantu petani melakukan penataan pengelolaan usahatani agroforestri melalui adopsi teknologi M-Bio agar produksi dan produktivitas meningkat untuk meningkatkan pendapatan dan keberlanjutan usahataninya.

\section{TINJAUAN LITERATUR}

Penelitian dilaksanakan di Desa Setiawaras Kecamatan Cibalong Kabupaten Tasikmalaya dari Bulan Juli 2020 sampai Bulan Oktober 2020. Desa Setiawaras ini merupakan salah satu desa di samping enam desa lainnya (Parung, Eureunpalay, Cisempur. Dalam upaya mendukung keberlanjutan usahatani dan kelestarian fungsi lahan kering berbagai usaha telah dan sedang dilakukan berkaitan dengan tingginya potensi lahan kering dalam mendukung pembangunan 
pertanian baik pada sector tanaman pangan maupun non pangan serta timbulnya berbagai dampak dari pembangunan pertanian terhadap kelestarian ekosistem lahan kering (Ai Dariah dan Irsal Las, 2010).

Pembangunan pertanian di lahan kering jauh lebih kompleks dibandingkan dengan di lahan basah, sehubungan dengan potensi sumberdaya yang ada dibatasi oleh daya dukung alam yang relatif kurang, prasarana sosial ekonomi yang belum merata, kelembagaan sosial ekonomi yang belum menjangkau masyarakat setempat serta mutu sumberdaya manusia yang relatif masih rendah. Sumberdaya lahan kering juga memiliki kondisi yang sangat beragam dan kondisi iklim yang selalu berubah, sehingga sering menjadi kendala untuk menentukan efektivitas implementasi teknologi pengelolaan lahan yang ada.

Nono Sutrisno, et., al.. (2010) menyatakan bahwa sektor pertanian dalam menghadapi perubahan iklim, harus mengembangkan pertanian yang tahan terhadap perubahan iklim dan harus dibuat sebagai peluang untuk meningkatkan produktivitas. Pertanian lahan kering harus dapat memperkuat kemampuannya agar tetap berproduksi tinggi, dalam arti harus memiliki strategi adaptif yang tepat dan bahkan bisa memitigasi dampak negatif perubahan iklim.

Usaha adaptasi pada pertanian lahan kering dilakukan dengan menerapkan sistem pengelolaan lahan dan air secara terpadu dan tepat supaya sistem pertanian dapat berproduksi secara berkelanjutan. Sesuai dengan karakteristik dan keterbatasan yang dimiliki lahan kering, maka menurut Abdurahman, et., al.., (1997) pola pengembangan pertanian yang sesuai adalah pola usaha tani terpadu. Usaha tani terpadu/terintegrasi merupakan sistem pertanian yang dicirikan dengan keterkaitan yang erat antara komponen tanaman dengan ternak dalam suatu wilayah atau suatu usahatani (Pasandaran, et. al., 2005).

Upaya meningkatkan produksi pertanian pada lahan kering memerlukan pemahaman menyeluruh mengenai kompleksitas persoalan potensi lahan. Pengelolaan lahan yang keliru akan menurunkan bahkan merusak potensi yang ada dan pada akhirnya menyengsarakan masyarakat (Husain, et., al.., 2004). Usahatani terpadu dapat tercapai dengan baik apabila terjadi pemanfaatan diantara faktor produksi yaitu sumberdaya manusia, modal, alam serta pengelolaannya sehingga dengan adanya pemanfaatan ke empat sumberdaya tersebut akan memberikan ciri teknologi usahatani berupa luas garapan, jumlah ternak, penggunaan tenaga kerja, penggunaan modal, pemilihan pola tanam serta memilih kombinasi usaha yang dianggap paling menguntungkan (Prodjodihardjo, 1988).

Kesinambungan sumberdaya lahan melalui usahatani polikultur perkebunan/Agroforestri akan dapat dipertahankan dengan adanya beberapa jenis tanaman yang diusahakan pada lahan yang sama. Kokoye et., al. (2013) mengatakan bahwa pilihan penggunaan lahan dalam usahatani sangat 
berhubungan erat dengan keputusan petani yang berkenaan dengan penggunaan lahan aktual. Hal ini dipengaruhi oleh rasionalitas petani yang antara lain dipengaruhi oleh berbagai tujuan antara lain : menjamin ketahanan pangan rumah tangga, menjamin pendapatan tunai/ penghasilan untuk memenuhi kebutuhan, meminimisasi risiko, memaksimisasi leisure terkait alokasi waktu, menjamin anggota keluarga dalam kondisi baik dan sejahtera, serta meraih kelas social tertentu dalam komunitasnya.

Berkenaan dengan hal tersebut maka diperlukan adopsi teknologi untuk pengelolaan usahatani agroforestri melalui usahatani terpadu agar produktivitasnya meningkat. Rogers dan Shoemaker (1983) menjelaskan bahwa adopsi merupakan proses mental dalam mengambil keputusan untuk menerima atau menolak ide baru dan menegaskan lebih lanjut terkait penerimaan dan penolakan ide baru tersebut. Ray, 1998, mengemukakan lima tahap proses adopsi yaitu: (1) Awareness (tahu dan sadar), pertama kali mendapat suatu ide dan praktek baru, (2) Interest (minat), mencari rintisan informasi, (3) Evaluation (evaluasi), menilai manfaat inovasi yaitu penilaian tentang untung ruginya sesuatu inovasi bila ia melaksanakannya (mudah dikerjakan), (4) Trial (mencoba), mencoba menerapkan ivovasi pada skala kecil, (5) Adoption (adopsi), menerapkan inovasi pada skala besar pada usahataninya.

Suparlan (1981) menyatakan bahwa adopsi inovasi dipengaruhi oleh (a) tidak bertentangan dengan pola kebudayaan yang telah ada, (b) struktur sosial masyarakat dan pranata sosial, dan (c) persepsi masyarakat terhadap inovasi. Kecepatan proses adopsi dipengaruhi oleh klasifikasi pengadopsi, ciri-ciri pribadi, sosial, budaya dan lingkungan serta sumber informasi.

Perilaku petani dalam adopsi inovasi dapat dipahami dengan menggunakan berbagai perspektif. Perspektif kognitif dalam memahami perilaku petani memberikan penekanan atau perhatian pada aspek mental dalam memahami perilaku sosial. Aspek sikap sebagai faktor yang mempengaruhi perilaku diartikan sebagai kesiapan untuk menanggapi dengan cara tertentu dan menekankan implikasi perilaku (Sears, Freedman dan Peplau, 1999). Sikap memiliki tiga bagian yaitu kesadaran, pengetahuan atau keyakinan (kognitif), perasaan (afektif) dan kecenderungan bertingkah laku (konatif) (Sarwono, 2002).

\section{METODE PELAKSANAAN}

\section{Lokasi dan Waktu Penelitian}

Penelitian dilaksanakan di Desa Setiawaras Kecamatan Cibalong Kabupaten Tasikmalaya dari Bulan Juli 2020 sampai Bulan Oktober 2020. Desa Setiawaras ini merupakan salah satu desa di samping enam desa lainnya (Parung, Eureunpalay, Cisempur, Cibalong dan Singajaya) yang ditetapkan sebagai lokasi penelitian karena Desa Setiawaras memiliki luas area terluas dari seluruh desa yang ada di Kecamatan Cibalong yaitu mencapai 1.829 ha atau sekitar 31 persen dari luas total kecamatan 
Cibalong dengan rata-rata ketinggian tempat $400 \mathrm{~m} \mathrm{dpl}$.

\section{Penentuan Responden}

Dari Desa Setiawaras ditetapkan

2 kelompok tani sebagai responden berdasarkan rekomendasi dari Bapak kepala desa Setiawaras yaitu kelompok tani Cipigan Insan Mandiri dan Kelompok tani Dadap Sari yang selanjutnya diambil sebagai responden 18 orang petani dari kelompok tani Dadap Sari dan 19 orang petani dari kelompok tani Cipigan Insan Mandiri sehingga jumlah keseluruhan responden adalah sebanyak 37 orang petani.

\section{Metode Penelitian, Teknik Pengumpulan Data dan Analisis data}

Metode penelitian yang digunakan adalah survey dengan teknik pengumpulan data berupa observasi dan wawancara mendalam dengan responden. Varibel penelitian untuk mengukur perilaku petani terhadap Teknologi M-Bio yang disampaikan pada program diseminasi Teknologi kepada masyarakat mencakup pelaksanaan penyuluhan dan pelatihan serta sikap petani terhadap penerapan teknologi M-Bio. Parameter yang digunakan untuk mengukur perilaku petani pada pelaksanaan penyuluhan dan pelatihan meliputi : presentasi dan praktek, atensi, komprehensif, hasil dan retensi. Sedangkan parameter untuk mengukur perilaku petani dalam mengadopsi teknologi M-Bio adalah aspek kognitif, afektif dan konatif.

Kerangka analisis yang digunakan adalah analisis deskriptif dengan melakukan penilaian perilaku tiap parameter yang diamati menggunakan skala likert yaitu skor 1, 2, 3, 4, dan 5. Skor 1 atau minimum menunjukkan nilai jawaban yang paling tidak diharapkan dan skor 5 atau skor maksimum menunjukkan nilai dari jawaban yang sangat diharapkan. Selanjutnya data dianalisis dengan tabulasi silang dan diukur dengan nilai tertimbang. Nilai tertimbang ini merupakan presentase nilai yang berasal dari pengukuran indikator-indikator atau variabel dengan menggunakan rumus (Djoni, 2008) sebagai berikut:

$$
\mathrm{NT}=\frac{\text { Nilai yang didapat }}{\text { Nilai ideal } / \text { maksimal }} \times 100 \%
$$

Dengan penghitungan rumus tersebut, maka sebaran data berubah menjadi skala rasio dengan skor berkisar antara 0-100. Untuk keperluan interpretasi, skor dikelompokkan menggunakan empat jenjang tingkatan sebagai berikut: (1) Sangat Rendah berada pada kisaran nilai 0-20; (2) Rendah berada pada kisaran nilai 21-40; (3) Sedang berada pada kisaran nilai 4160 ; (4) Tinggi berada pada kisaran 6180; dan (5) Sangat Tinggi berada pada kisaran 81-100.

\section{HASIL DAN PEMBAHASAN}

\section{Identitas Responden}

Identitas responden yang dikaji pada penelitian ini dilihat dari aspek umur, pendidikan terakhir, pekerjaan pokok, pekerjaan sampingan, pengalaman berusahatani agroforestri, jumlah tanggungan keluarga, dan lama menjadi anggota kelompok tani (Tabel 1). 
Tabel 1. Identitas Responden

\begin{tabular}{|c|c|c|c|}
\hline No & Uraian & Jumlah (Orang) & Persentase (\%) \\
\hline \multirow[t]{4}{*}{1} & Umur: & & \\
\hline & $\bullet<15$ & 0 & 0,00 \\
\hline & • 15-64 & 32 & 86,49 \\
\hline & $\bullet>64$ & 5 & 13,51 \\
\hline \multirow[t]{5}{*}{2} & Pendidikan Terakhir & & \\
\hline & - SD & 6 & 16,22 \\
\hline & - SMP & 15 & 40,54 \\
\hline & - SMA & 14 & 37,84 \\
\hline & - $\mathrm{S} 1$ & 2 & 5,41 \\
\hline \multirow[t]{7}{*}{3} & Pekerjaan Pokok & & \\
\hline & - Petani & 22 & 59,46 \\
\hline & - Pedagang/Wiraswasta & 5 & 13,51 \\
\hline & - Perangkat Desa & 2 & 5,41 \\
\hline & - Buruh Harian Lepas & 4 & 10,81 \\
\hline & - Perangkat Wilayah & 3 & 8,11 \\
\hline & - Mengurus Rumah Tangga & 1 & 2,70 \\
\hline \multirow[t]{18}{*}{4} & Pekerjaan Sampingan & & \\
\hline & - Berkebun & 1 & 2,70 \\
\hline & - Budi Daya Ikan & 1 & 2,70 \\
\hline & - Buruh & 3 & 8,11 \\
\hline & - Buruh Tani & 1 & 2,70 \\
\hline & • Guru Honorer & 1 & 2,70 \\
\hline & - Jual Beli Barang Pokok & 1 & 2,70 \\
\hline & - Jual Beli Hasil Bumi & 1 & 2,70 \\
\hline & - Mengurus Rumah Tangga & 1 & 2,70 \\
\hline & - Nyadap & 1 & 2,70 \\
\hline & - Pedagang & 3 & 8,11 \\
\hline & - Penjahit & 1 & 2,70 \\
\hline & - Perikanan & 1 & 2,70 \\
\hline & - Petani & 8 & 21,62 \\
\hline & - Peternak & 5 & 13,51 \\
\hline & - Tukang Listrik & 1 & 2,70 \\
\hline & - Tukang Ojek & 1 & 2,70 \\
\hline & - Tidak ada Pekerjaan Sampingan & 6 & 16,22 \\
\hline
\end{tabular}




\begin{tabular}{|c|c|c|c|}
\hline No & Uraian & Jumlah (Orang) & Persentase (\%) \\
\hline \multirow[t]{3}{*}{5} & Pengalaman Usahatani Agroforestry & & \\
\hline & - 1-10 Tahun & 34 & 91,89 \\
\hline & - $>10$ Tahun & 3 & 8,11 \\
\hline \multirow[t]{4}{*}{6} & Jumlah Tanggungan Keluarga & & \\
\hline & - 0 -2 Orang & 14 & 37,84 \\
\hline & - 3-5 Orang & 22 & 59,46 \\
\hline & - 6-8 Orang & 1 & 2,70 \\
\hline \multirow[t]{4}{*}{7} & Lama Menjadi Anggota Kelompok Tani & & \\
\hline & - 1-5 Tahun & 13 & 35,14 \\
\hline & - 6-10 Tahun & 21 & 56,76 \\
\hline & - 11-20 Tahun & 3 & 8,11 \\
\hline
\end{tabular}

Sumber : Data primer diolah, Tahun 2020.

Umur petani rata-rata berada pada kategori umur produktif (15-64 tahun), Tingkat pendidikan didominasi oleh petani yang berpendidikan SMP dan SMA. Hal ini menunjukkan tingkat pendidikan formal petani responden sudah memperlihatkan adanya peningkatan, karena umumnya pendidikan petani didominasi oleh petani dengan pendidikan SD bahkan tidak tamat SD. Tingkat pendidikan formal merupakan salah satu faktor yang dapat membantu untuk meningkatkan adopsi teknologi terkait upaya peningkatan produksi dan produktivitas usahatani. Meskipun ada kajian lain yang menunjukkan bahwa sikap tidak berhubungan dengan karakteristik individu petani yang terdiri atas pendidikan formal, pendidikan nonformal, pengalaman berusahatani, status lahan, luas lahan, pekerjaan utama, dan jenis kelamin (Rahma, $d k k, 2019$ )

Pekerjaan pokok responden umumnya adalah petani $(59,46 \%)$ diikuti dengan pedagang/wiraswasta $(13,51 \%)$ dan pekerjaan lainnya. Pengalaman usahatani agroforestri berkisar antara 110 tahun $(91,89 \%)$ dan lebih dari 10 tahun $(8,11 \%)$. Jumlah tanggunan keluarga petani paling banyak berada pada kisaran 3-5 orang $(59,46 \%)$ dan 02 orang $(37,82 \%)$ serta $6-8$ orang $(2,70 \%)$ serta lama menjadi anggota kelompok tani paling banyak ada diantara 6-10 tahun $(56,76 \%)$.

\section{Perilaku Petani Terhadap Pelaksanaan Penyuluhan dan Pelatihan}

Perilaku petani terhadap pelaksanaan penyuluhan dilihat dari indikator presentasi dan praktek, atensi, komprehensif, hasil dan retensi. Hasil analisis tentang perilaku petani terhadap pelaksanaan penyuluhan dan pelatihan secara keseluruhan dan pada masingmasing indikator dapat dilihat pada Tabel 2. 
Tabel 2. Skor Perilaku Petani Terhadap Pelaksanaan Penyuluhan dan Pelatihan Teknologi M-Bio

\begin{tabular}{llcccc}
\hline No & \multicolumn{1}{c}{ Indikator } & $\begin{array}{c}\text { Nilai } \\
\text { Tertimbang } \\
(\mathbf{\%})\end{array}$ & $\begin{array}{c}\text { Skor } \\
\text { yang } \\
\text { dicapai }\end{array}$ & $\begin{array}{c}\text { Skor } \\
\text { Ideal }\end{array}$ & Kategori \\
\hline $\mathbf{1}$ & Presentasi dan praktek & 90,45 & 502 & 555 & Sangat tinggi \\
\hline $\mathbf{2}$ & Atensi & 85,95 & 318 & 370 & Sangat tinggi \\
\hline $\mathbf{3}$ & Komprehensif & 92,43 & 342 & 370 & Sangat tinggi \\
\hline $\mathbf{4}$ & Hasil & 89,19 & 330 & 370 & Sangat tinggi \\
\hline $\mathbf{5}$ & Retensi & 87,84 & 325 & 370 & Sangat tinggi \\
\hline & \multicolumn{1}{c}{ Jumlah } & 89,39 & 1.819 & 2.035 & Sangat tinggi \\
\hline
\end{tabular}

Sumber : Data primer diolah, tahun 2020.

Data pada Tabel 2 menunjukkan bahwa total skor perilaku petani terhadap pelaksanaan penyuluhan dan pelatihan termasuk dalam kategori sangat tinggi $(89,39 \%)$. Demikian juga untuk masingmasing indikator pelaksanaan penyuluhan dan pelatihan semuanya termasuk dalam kategori sangat tinggi.

Skor perilaku petani indikator presentasi dan praktek terkategori tinggi $(90,45 \%)$ terkait dengan peserta memahami penjelasan dan praktek yang disampaikan pada penyuluhan dan pelatihan program diseminasi teknologi M-Bio. Penjelasan dan praktek aplikasi teknologi M-Bio disampaikan secara rinci melalui pertemuan yang diselenggarakan dalam bentuk tatap muka di balai desa antara pelaksana program dengan petani dilengkapi dengan tampilan materi penyuluhan melalui tayangan power point dan simulasi audio visual.
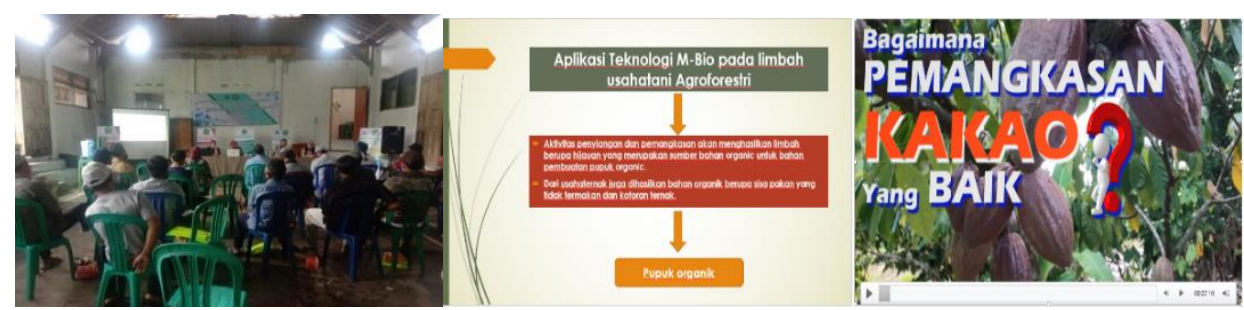

Gambar 1. Pelaksanaan kegiatan dan Tayangan PPT serta audio visual pada aktivitas penyuluhan PTDM Tentang Teknologi M-Bio

Selain itu petani juga melaksanakan praktek langsung di lapangan tentang aplikasi teknologi MBio baik aplikasi pada pembuatan pupuk organik, pada pembuatan pakan, persiapan kolam, dan perlakuan pemberian M-Bio pada pakan ikan untuk meningkatkan kualitas pakan ikan 
sehingga petani mendapatkan gambaran detil dari teknologi yang disampaikan. Hal tersebut diperkuat dengan penjelasan dan praktek pelaksanaan program diseminasi teknologi M-Bio dilaksanakan sesuai dengan permasalahan yang dihadapi petani dimana usahatani agroforestri merupakan usahatani yang telah lama ditekuni petani dan telah berlangsung secara terus menerus sehingga petani memiliki perhatian dan bersemangat untuk mengikutinya.

Terkait dengan skor perilaku petani indikator atensi yang juga terkategori sangat tinggi $(85,95 \%)$ berkenaan dengan petani memberikan perhatian terhadap penjelasan yang disampaikan pada kegiatan penyuluhan serta memberikan perhatian terhadap pelaksanaan praktek pada kegiatan pelatihan program diseminasi teknologi M-Bio. Atensi yang baik dari para peserta juga tercermin dari skor perilaku petani indikator komprehensif yang terkategori sangat tinggi $(92,43 \%)$, dimana petani mengikuti pelaksanaan dan praktek program diseminasi teknologi M-Bio dari awal sampai akhir termasuk mengikuti pelaksanaan dan praktek program diseminasi tekbologi yang membantu mengatasi permasalahan petani.

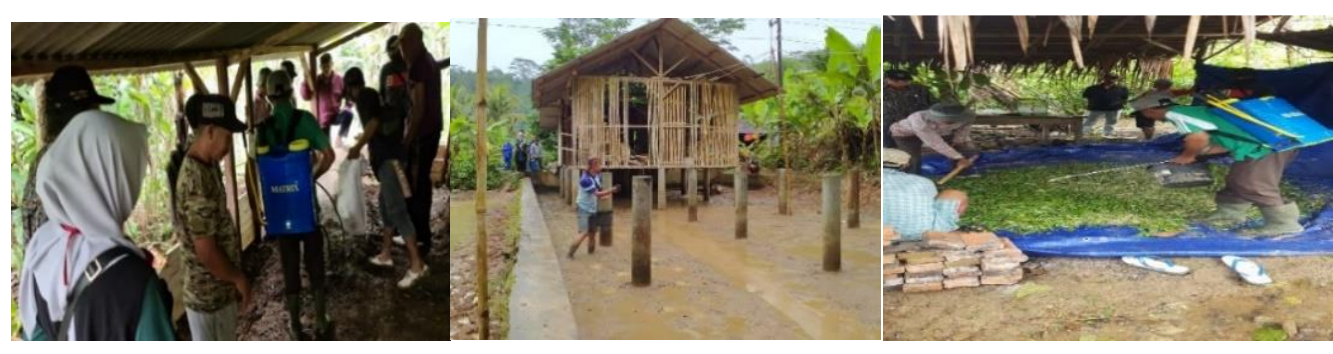

Gambar 2. Pelaksanaan kegiatan praktek yang dilakukan pada aktivitas pelatihan PTDM tentang Teknologi M-Bio.

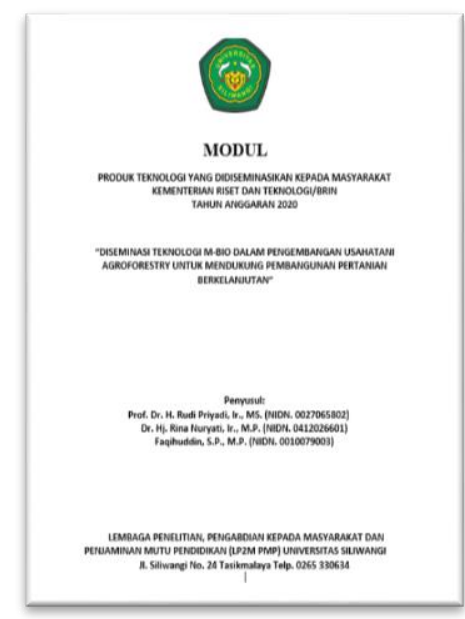

Gambar 3. Modul aplikasi Teknologi M-Bio pada usahatani agroforestri yang diberikan kepada petani peserta program. 
Skor perilaku petani indikator hasil terkategori sangat tinggi $(89,19 \%)$, sehubungan dengan pelaksana membantu untuk memahami penjelasan dan praktek serta membantu untuk menerapkan hasil penyuluhan dan praktek program diseminasi teknologi M-Bio Begitu juga dengan skor perilaku petani indikator retensi terkategori sangat tinggi $(87,84 \%)$ karena peserta selalu mempelajari kembali materi yang disampaikan dan selalu berusaha mencoba menerapkan materi yang disampaikan. Hal ini disebabkan pada kegiatan penyuluhan dan pelatihan petani diberi modul yang merupakan pedoman lengkap tentang materi yang disampaikan baik tentang pengelolaan tanaman, ternak maupun ikan sehingga dapat dijadikan bahan untuk dipelajari kembali oleh petani.

\section{Perilaku Petani Terhadap Adopsi Teknologi M-Bio}

Perilaku petani terhadap adopsi teknologi M-Bio dilihat dari indikator aspek kognitif, aspek apektif dan aspek konatif. Hasil analisis tentang perilaku petani terhadap penerapan teknologi MBio dan masing - masing indikatornya dapat dilihat pada Tabel 3. Tabel 3 menunjukkan bahwa total skor perilaku petani terhadap penerapan teknologi MBio termasuk dalam kategori sangat tinggi $(89,82 \%)$. Demikian juga untuk masing-masing indikator pelaksanaan penyuluhan dan pelatihan semuanya termasuk dalam kategori sangat tinggi.

Tabel 3. Perilaku Petani Terhadap Adopsi Teknologi M-Bio.

\begin{tabular}{llllll}
\hline No & Indikator & $\begin{array}{l}\text { Nilai } \\
\text { Tertimbang } \\
(\%)\end{array}$ & $\begin{array}{l}\text { Skor yang } \\
\text { dicapai }\end{array}$ & $\begin{array}{l}\text { Skor } \\
\text { Ideal }\end{array}$ & Kategori \\
\hline 1 & Aspek kognitif & 90,81 & 336 & 370 & Sangat tinggi \\
\hline 2 & Aspek Apektif & 89.18 & 330 & 370 & Sangat tinggi \\
\hline 3 & Aspek Konatif & 89,46 & 331 & 370 & Sangat tinggi \\
\hline & Jumlah & 89,82 & 997 & 1.110 & Sangat tinggi \\
\hline
\end{tabular}

Sumber : Data primer diolah, tahun 2020

Skor perilaku petani pada ketiga indikator adopsi teknologi M-Bio meliputi aspek kognitif, aspek apektif dan aspek konatif semuanya terkategori sangat tinggi masing-masing dengan nilai tertimbang $90,81 \%, 89,18 \%$ dan $89,46 \%$. Hal ini berkaitan dengan peserta merasakan manfaat dari materi dan penerapan teknologi M-Bio yang disampaikan juga memiliki perasaan senang dan tertarik terhadap kegiatan dan materi diseminasi teknologi M-Bio. Selain itu petani juga memiliki kesadaran dan keyakinan untuk menerapkan teknologi M-Bio yang deseminasikan.

Materi penyuluhan dan pelatihan pada kegiatan PTDM sudah disesuaikan dengan permasalahan yang ada petani, karena materi penyuluhan dan pelatihan 
disusun berdasarkan hasil kajian pendahuluan terhadap permasalahan yang dihadapi petani disertai dengan pelaksanaan FGD beserta pemerintah daerah, penyuluh, tokoh masyarakat, kelompok tani dan lainnya untuk menggali lebih rinci permasalahan petani yang dihadapi petani pada aktivitas usahatani.

Pola usahatani agroforestri yang dilakukan petani sangat bervariasi atau beragam, ada yang melakukan usahatani agroforestrinya dengan pola tanamantanaman, ada pula dengan pola tanamanternak dan tanaman-ikan serta terdapat pula yang merupakan kombinasi di antara ketiganya yaitu pola tanamanternak-ikan. Pola tanam ini merupakan usahatani yang telah dilakukan secara turun temurun dari satu generasi ke generasi berikutnya serta merupakan norma yang dikembangkan dari bentuk usahatani berdasarkan kearifan lokal.

Permasalahan umum yang ditemui petani adalah produksi dan produktivitas usahatani agroforestrinya yang masih rendah, diantaranya adalah tanaman kelapanya rata-rata hanya menghasilkan 45 butir/pohon/tahun, kakao dan kopi rata-rata produktivitasnya masingmasing hanya mencapai 0,50 ton/ha untuk tanaman kakao dan 0,49 ton/ha untuk tanaman kopi (Statistik Perkebunan Tahun 2013 Kab. Tasikmalaya), padahal potensi produksi kakao dapat mencapai 2,16-3,20 ton/ha (Tri Haryanto, 2012) dan untuk tanaman kopi bisa mencapai $0,5-1,2$ ton/ha (Djaenudin, et al., 2003).

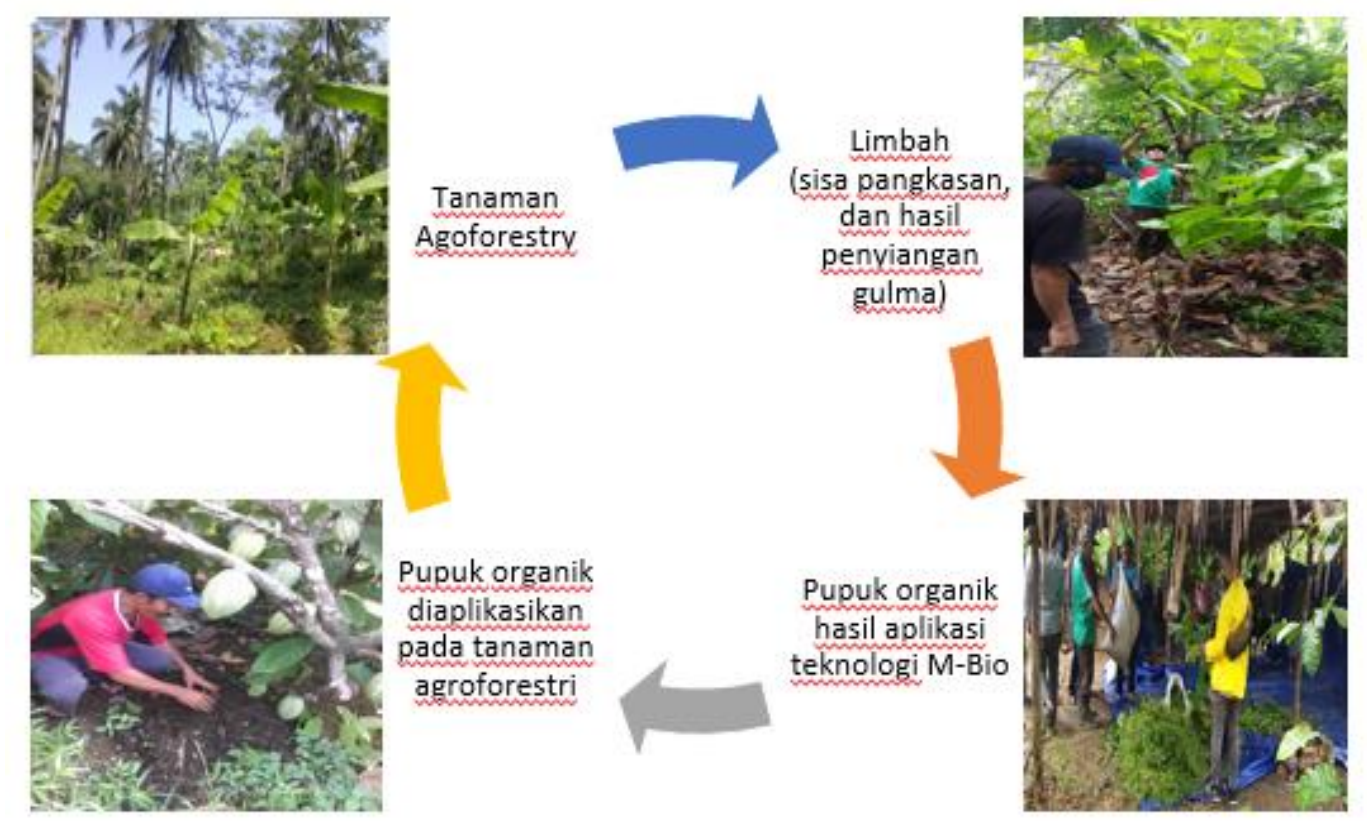

Gambar 4. Penataan Pengelolaan Usahatani Agroforestri dengan Teknologi M-Bio pada pengelolaan Usahatani terpadu untuk pola Tanaman - Tanaman.

Begitu pula dengan kondisi usaha ternak dan usaha perikanannya, di mana kandang terlihat kotor dan kurang terawat dengan ceceran limbah kandang 
dan sisa pakan berserakan di sekitar sentuhan teknologi sehingga kandang sehingga pertumbuhan dan perkembangan ternak tidak optimal. pemanfaatan pakan alami tidak Usaha perikanan juga dilakukan tanpa maksimal.

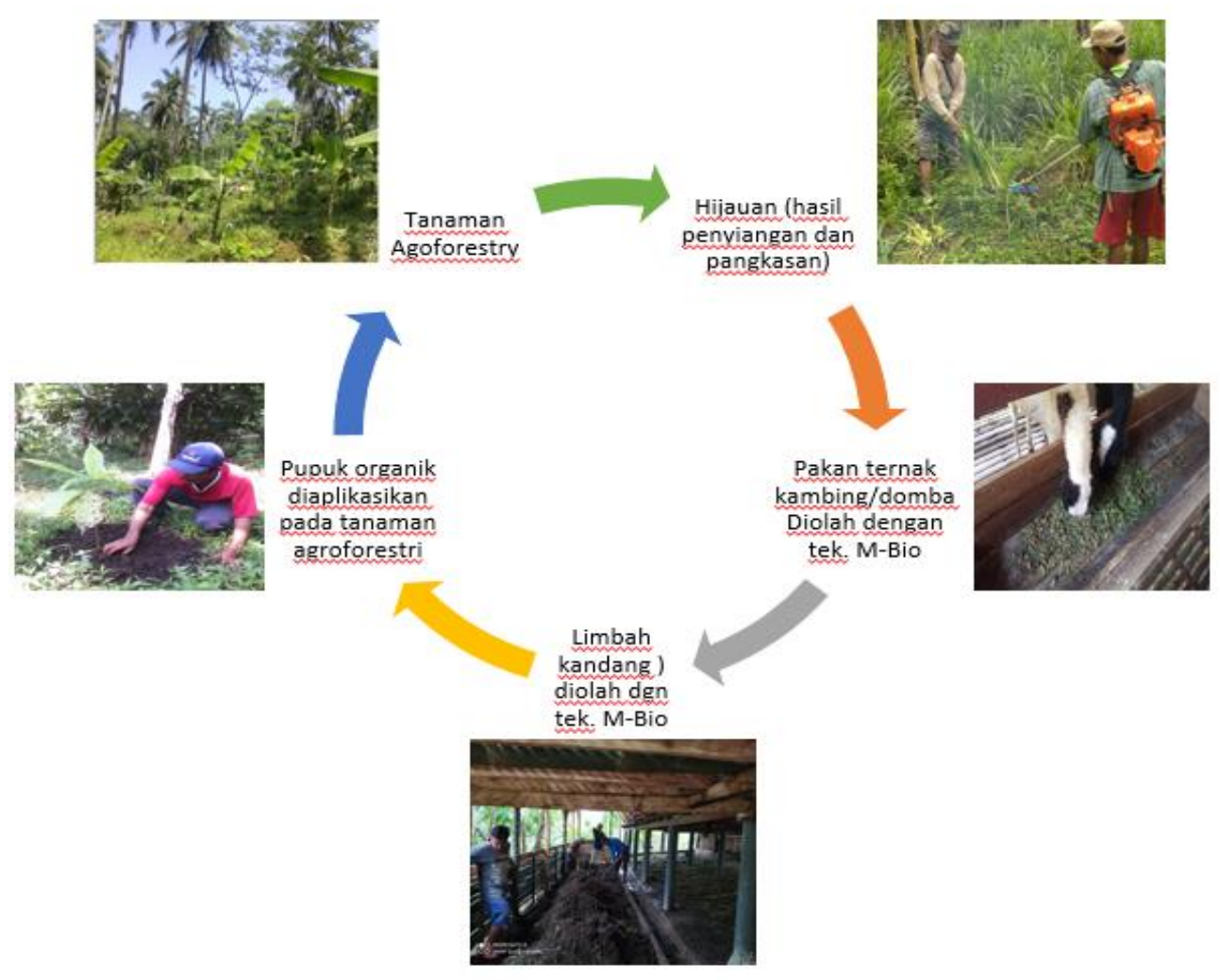

Gambar 5. Penataan Pengelolaan Usahatani Agroforestri dengan Teknologi M-Bio pada pengelolaan Usahatani terpadu untuk pola Tanaman - Ternak.

Teknologi M-Bio dideseminasikan pada usahatani agroforestri yang dikelola petani ditujukan untuk melakukan penataan pengelolaan usahatani agroforestri dengan mengembangkannya pada usahatani terpadu atau usahatani terintegrasi. Pada pola usahatani tanaman-tanaman, teknologi M-Bio digunakan pada proses pengelolaan hijauan dari hasil pemangkasan tanaman agroforestri dan hasil penyiangan gulma yang tumbuh pada areal lahan usahatani agroforestri menjadi pupuk organik yang selanjutnya diaplikasikan kembali pada tanaman agroforestri.

Sementara itu pada pola usahatani tanaman - ternak, teknologi M-Bio digunakan pada pembuatan pakan ternak yang berbahan baku hijauan yang berasal dari hasil pemangkasan tanaman agroforestri berupa daun, cabang atau ranting serta dari hasil penyiangan gulma pada lahan agroforestri ditambah limbah panen berupa kulit buah dan kulit biji serta bagian lainnya.

Komposisi pakan berupa berbagai hijauan, limbah Cacao (Kulit buah 
cacaonya), dedak dan daun pisang. Bahan tersebut, dicacah kemudian dicampurkan dengan perbandingan $1: 1$ dan diaduk agar merata, selanjutnya disemprot dengan M-Bio pada konsentrasi $5 \mathrm{ml} /$ liter air, kemudian didiamkan selama 2-4 jam agar proses fermentasi berlangsung sempurna. Pakan diberikan sebanyak 3 kali sehari pada pagi, siang dan sore hari dengan kebutuhan pakan sebanyak $45 \mathrm{~kg}$ untuk 40 ekor kambing/domba. Dari usaha ternak akan dihasilkan limbah kandang berupa kotoran ternak yang juga merupakan bahan organik sebagai bahan baku pembuatan pupuk organik. Teknologi M-Bio digunakan untuk memfermentasi limbah kandang menjadi pupuk organik yang selanjutnya diaplikasikan pada tanaman agroforestri.

Pola usahatani tanaman - ikan, teknologi M-Bio seperti pada pola usahatani tanaman - tanaman dimanfaatkan untuk pembuatan pupuk organik yang berasal dari tanaman agroforestri dan gulma. Pupuk organik yang dihasilkan pada pola usahatani tanaman - ikan ini dimanfaatkan untuk meningkatkan kesuburan kolam guna meningkatkan pertumbuhan pakan alami berupa flankton. Oleh karena itu pupuk organik pada pola ini diberikan dengan cara ditabur pada dasar kolam. Dalam upaya meningkatkan pertumbuhan pakan alami, M-Bio juga diaplikasikan secara langsung pada dasar kolam setelah penaburan pupuk organik. Dari hasil monitoring dan evaluasi terungkap dengan cara ini ikan menjadi jarang muncul ke permukaan kolam. Hal ini semula menjadi kekhawatiran petani akan hilangnya ikan dari dalam kolam budidaya. Akan tetapi setelah diamati dengan seksama, ikan tersebut ada di dalam kolam. Lebih lanjut menurut petani, hal ini diduga karena adanya aplikasi pupuk organik hasil fermentasi M-Bio yang mampu memperbaiki kondisi kolam sehingga plankton dapat berkembang dengan baik dan dapat memenuhi kebutuhan ikan akan pakan alami.

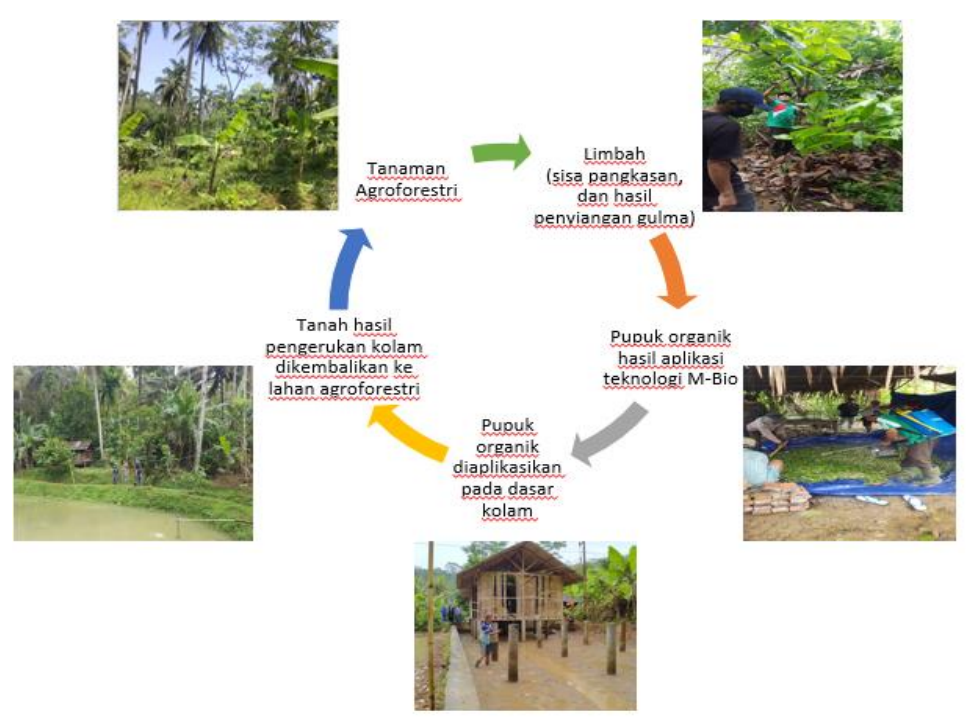

Gambar 6. Penataan Pengelolaan Usahatani Agroforestri dengan Teknologi M-Bio 
pada pengelolaan Usahatani terpadu untuk pola Tanaman - Ikan.

Petani lainnya yang sudah menerapkan teknologi M-Bio memberikan penguatan terhadap argumen yang disampaikan oleh petani yang bersangkutan dan nara sumber, bahwa melalui perlakuan M-Bio pada bahan organik untuk pembuatan pupuk organik menyebabkan ikan nila jarang muncul ke permukaan karena pada dasar kolam terdapat banyak plankton sebagai sumber pakan sehingga ikan tidak perlu ke permukaan untuk mencari pakan. Oleh karena itu, pada budidaya ikan nila dengan teknologi M-Bio ada petunjuk pemberian pakan dimana ada saat-saat tertentu tidak perlu dilakukan pemberian pakan karena kebutuhan pakan terpenuhi dari pakan alami. Hal ini sekaligus merupakan upaya untuk meningkatkan efisiensi penggunakan pakan yang biasanya merupakan komponen biaya tertinggi dari usaha di bidang perikanan.

Selain itu, M-Bo juga berperan sebagai enzim yang dapat meningkatkan kualitas pakan, karena M-Bio merupakan pupuk hayati yang mengandung Mikroba Pelarut Pospat. Lactobacillus sp, Mikroba Penambat Nitrogen, Yeast dan kandungan bahanbahan Organik lainnya. Hal ini sesuai dengan pernyataan Nachrowi (2016) yang menyatakan bahwa enzim merupakan senyawa protein dapat larut yang diproduksi oleh organisme hidup dan berfungsi sebagai katalisator untuk mempercepat reaksi pemecahan senyawa-senyawa organik yang kompleks menjadi sederhana. Enzim dapat meningkatkan nilai nutrisi (nutrient value) pakan sehingga dapat dimanfaatkan secara lebih baik.

Dengan demikian usahatani agroforestri dengan aplikasi teknologi M-Bio memanfaatkan keterkaitan antara cabang usahatani yang satu dengan cabang usahatani yang lainnya sehingga diantara keduanya dapat saling melengkapi karena output dari cabang usahatani yang satu menjadi input cabang usahatani lainnya. Pengelolaan usahatani terpadu ini dapat meningkatkan efektivitas dan efisiensi usahatani yang dilakukan untuk meningkatkan pendapatan petani dan keberlanjutan usahatani yang bersangkutan.

\section{PENUTUP}

\section{Kesimpulan}

Dari hasil pembahasan dapat disimpulkan hal-hal sebagai berikut :

1) Perilaku petani terhadap pelaksanaan penyuluhan dan pelatihan teknologi M-Bio untuk pengembangan usahatani agroforestri dengan seluruh indikatornya (presentasi dan praktek, atensi, komprehensif, hasil dan retensi) terkategori sangat tinggi.

2) Perilaku petani terhadap adopsi teknologi M-Bio untuk pengembangan usahatani agroforestri beserta seluruh indikatornya yang menyangkut aspek kognitif, apektif, dan konatif semuanya juga terkategori sangat tinggi.

\section{Saran}

Saran yang disampaikan terkait penelitian ini adalah perlu terus 
dilakukan upaya untuk mendayagunakan teknologi yang telah dihasilkan baik oleh lembaga penelitian maupun lembaga pendidikan dan lembaga lainnya guna membantu petani

mengatasi permasalahan yang dihadapinya. Teknologi yang sesuai dengan permasalahan yang dihadapi petani akan diadopsi oleh petani dengan baik.

\section{DAFTAR PUSTAKA}

Dinas Kehutanan dan Perkebunan Kabupaten Tasikmalaya, dalam Data Profil Kabupaten Tasikmalaya, 2015.

Djaenuddin, Marwan H., H. Subagyo., Mulyani, Anny., Suharta. 2003. Kriteria Kesesuaian Lahan Untuk Komoditas Pertanian Versi 4. Jakarta: Pusat Penelitian Tanah dan Agroklimat, Badan Penelitian dan Pengembangan Pertanian.

Fikagandhi. 2012. Pentingnya kearifan Lokal Masyarakat Dalam Pengelolaan Sumberdaya Alam dan Lingkungan di Pedesaan.

Nachrowi. 2016. Menghemat Biaya Pakan dengan Teknologi Enzim. Kementrian Pertanian Direktorat jenderal Peternakan dan Kesehatan Hewan. Tanggal posting 13 Juni 2016. Publikasi : Admin. Hits : 9233.

Panggabean, M. T., Amanah, S., dan Tjitropranoto, P. 2016. Persepsi Petani Lada terhadap Diseminasi Teknologi Usahatani Lada di Bangka Belitung. Jurnal
Penyuluhan, Maret 2016 Vol. 12 No. 1

Rahma, H., Wahyuni, S., Trisno, J., Martinius, dan Noveriza, R. 2019. Perilaku Petani dalam Menerapkan Teknologi BP3T (Bakteri Perakaran Pemacu Pertumbuhan Tanaman) Pupuk Kandang untuk Tanaman Kakao di Kabupaten Limapuluh Kota. Jurnal Penyuluhan, September 2019, Vol. 15 No. 2

Reijntjes, C., Haverkort, B. dan Bayer, A.W. 1999. Pertanian Masa Depan, Pengantar untuk Pertanian Berkelanjutan dengan Input Luar Rendah. ILEIA. Yogyakarta: Penerbit Kanisius, pp: 88-107.

Ris Irianto. 2010. Pembangunan Kebun Rakyat Pola Agroforestri (Hutan Rakyat) Meningkatkan Pendapatan Petani Dan Berwawasan Lingkungan di Kabupaten Kespahiang.

Rosales, G., and Mercado, W. 2020. Effect of changes in food price on the quinoa consumption and rural food security in Peru. Scientia Agropecuaria 11(1): 83-93.

Samingan T (1993) Fundamental of Ecology. In Odum P.E. (1959) (Transl.). Dasar-dasar Ekologi. Edisi Ketiga Gajahmada. Yogyakarta

Siche, Raul. 2020. What is the impact of COVID-19 disease on agriculture? Scientia Agropecuaria 11(1): 3 - 6 (2020). Ciudad Universitaria: Trujillo, Peru. 
DOI: https://doi.org/10.21009/sarwahita.191.7

P-ISSN: 0216-7484

E-ISSN: 2597-8926

Yuniarsih, E.T., Tenriawaru, A. N., Haerani, S., dan Syam, A. 2020. Analisis korelasi sikap petani dengan adopsi teknologi budidaya cabai di sulawesi selatan. Jurnal Pengkajian dan Pengembangan Teknologi Pertanian, Vlo. 23. No.

3 tahun 2020 